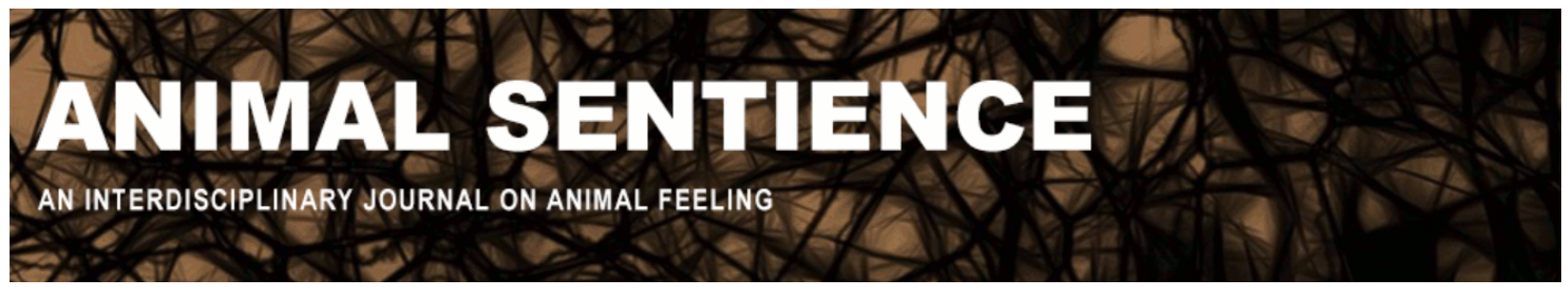

Lovell, Jarret S. (2020) Plant-based diets and COVID-19: Those who harvest crops are at high risk. Animal Sentience 30(10)

DOI: $10.51291 / 2377-7478.1638$

Date of submission: 2020-09-02

Date of acceptance: 2020-09-02 (c) (†) 


\title{
Plant-based diets and COVID-19: Those who harvest crops are at high risk
}

Commentary on Wiebers \& Feigin on Covid Crisis

\author{
Jarret S. Lovell
}

Division of Politics, Administration \& Justice

California State University, Fullerton (USA)

\begin{abstract}
This commentary extends Wiebers \& Feigin's (2020) plea to adopt diets that are less dependent on animals by calling on experts and activists to work for change with regard to farm worker labor conditions. Already doing among the most dangerous jobs, farmworkers are at increased risk of COVID-19. As we increasingly transition to plant-based diets, we must all ensure that farmworkers have safe and just working conditions to meet the demands of our changing diets.
\end{abstract}

Jarret S. Lovell is Professor of Politics, Administration and Justice at California State University, Fullerton (USA). Among his teaching and research interests are animals as victims, civil disobedience and nonviolent protest, and theories of social justice. Website

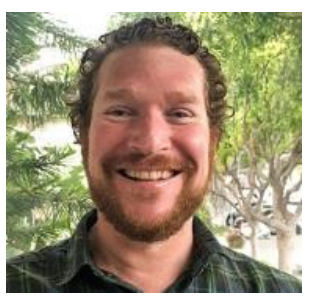

In late 2019 and early 2020, as the threat of COVID-19 began to spread, people around the world have had to reconsider their relationships with other living beings. Now, Wiebers \& Feigin (2020) (W\&F) argue in their important and cautionary target article that this reconsideration must extend to our relationship with (non-human) animals as sources of food. With $75 \%$ of new infectious diseases stemming in part from our dependence on animals as resources, with the industrialized farming of animals contributing to the destruction of the environment, and with factory farms being inhumane to animals and workers alike (Human Rights Watch, 2005), it is time that humans "rapidly evolve to eating other forms of protein that are safer for humans," such as plant-based agriculture, as W\&F urge.

Fortunately, it appears that people are already paying attention to what COVID-19 is telling humanity. According to the Plant-Based Food Association (PBFA, 2020), during the early weeks of the pandemic after the peak buying of food and toiletries subsided, plant-based food sales continued to grow at a rate of $27 \%$, with tofu sales up by nearly $33 \%$ (Zimberoff, 2020). Not only will this shift toward plant-based foods help to reduce the spread of zoonotic diseases; it will also mark an important step toward reducing the deleterious impact of animal agriculture on our environment; and it will diminish the unnecessary suffering and slaughter of animals on factory farms. Yet as we continue the necessary work to reduce the global dependence on animals for food and take comfort in the fact that we are replacing them with plant agriculture, we must be cognizant of a rather disheartening fact: The farmworkers who harvest our crops are 
among the populations at highest risk for contracting the COVID-19 virus (Tuiran and Roberts, 2020).

According to the U.S. Centers for Disease Control (CDC, 2019), farm work is among the occupations with the highest fatal and nonfatal injury rates. The U.S. Occupational Safety and Health Administration (OSHA) identifies several work-related hazards linked to farmworkers including pesticide and chemical exposure, nausea, dizziness, respiratory distress, urinary infections stemming from urine retention and lack of potable water, and other diseases as a result of poor toilet or bathroom facilities (OSHA, 2020). Heat-related illnesses are particularly common among farmworkers. With shifts lasting between eight and fourteen hours in the sun with minimal access to shade or water, the heat-related death rate for field-hands is nearly twenty-times greater for crop workers than for workers in other occupations (CDC, 2008).

There are also sociopolitical factors that that magnify the impact of the on-the-job health risks on farmworkers. A large constituency of U.S. field-hands are undocumented workers (Food Empowerment Project, 2020). Wages are therefore low, and workers have limited capacity to negotiate for better wages or working conditions, not to mention access to health care. It is also the case that females, who comprise roughly $28 \%$ of the farmworker labor force. are vulnerable to sexual harassment on the job; and they are often forced to sleep with their supervisors to maintain their jobs in the field (ACLU, 2007).

It is clear, then, that under non-pandemic circumstances the on-the-ground conditions for farmworkers are already dangerous, -- if not deadly. The threat of the Coronavirus exposes more farmworker vulnerabilities. Housing conditions for farm workers are poor. Many workers live in crowded, poorly ventilated trailers that house up to ten people (Wiltz, 2016). Farm workers (and rural communities in general) are also less likely to have access to doctors and hospital beds to treat the deadly Coronavirus. All of this explains new data revealing that farmworkers are three times more likely to contract the virus than non-agricultural workers (Villarejo, 2020).

The global community is thus confronted with a dilemma. It is clear that as COVID-19 continues to spread, people are waking up to the realization that our dependence on animals for food and other resources is dangerous to global health. At the same time, as we shift toward a plant-based diet, we increase our dependence on an industry that places the health of the most vulnerable workers at risk - including a risk of contracting the Coronavirus. It is incumbent upon all of us, then, that as we advocate for a transition to plant-based diets we do so ethically and humanely by working to improve labor conditions for farmworkers. The scientific and academic communities must work with labor organizers and consumers to ensure that the most vulnerable (human) members of the food production line receive protections - not only during this pandemic, but ubiquitously.

\section{References}

American Civil Liberties Union (2007). No free pass to harass: Protecting the rights of undocumented immigrant women workers in sexual harassment cases. New York. 
Centers for Disease Control (2008). Heat-related deaths among crop workers --- United States, 1992-2006.

Centers for Disease Control (2019). Agricultural safety. The National Institute for Occupational Safety and Health.

Food Empowerment Project (2020). Produce Workers. Cotati, CA.

Human Rights Watch (2005). Blood, sweat and fear: Workers' rights in U.S. meat and poultry plants. Human Rights Watch.

National Farm Worker Ministry (2018). Farm worker issues: Health and safety. Raleigh, N.C.

Plant Based Food Association (2020, May 26). New data shows plant-based food outpacing total food sales during COVID-19. PBFA News.

Runyon, L., Whitney, E. (2020, April 29). Workers Scared As Trump Orders Meat Plants To Open During Coronavirus Crisis. National Public Radio.

Turian, R., Roberts, N. (2020, July 21). Farmworkers are among those at highest risk for COVID19, studies show. PBS.org.

Occupational Safety and Health Administration (2020). Agricultural Operations. United States Department of Labor. Washington, D.C.

Villarejo, D. (2020). Increased risks and fewer jobs: Evidence of California farmworker vulnerability during the COVID-19 pandemic. California Institute for Rural Studies.

Wiebers, D.O., Feigin, V.L. (2020). What the COVID-19 crisis is telling humanity. Animal Sentience 30(1).

Wiltz, T. (2016, May 2). States struggle to provide housing for migrant farmworkers. Pew Research Center. Washington, D.C.

Zimberoff, L. (2020, June 11). Tofu goes mainstream in America thanks to big meat's Covid crisis. Bloomberg.com. 